\title{
触 New Disease Reports \\ First report of Microidium phyllanthi causing powdery mildew on chamber bitter in Vietnam
}

\author{
L.T.T. Tam ${ }^{1 *}$, H.T. Hoai ${ }^{1}$, L.P. Thao ${ }^{1}$, N.T. Huong ${ }^{1}$ and N.M. Khue ${ }^{2}$ \\ ${ }^{1}$ Division of Plant Pathology, Plant Protection Research Institute, Duc Thang, Bac Tu Liem, Hanoi, Vietnam; ${ }^{2}$ Plant \\ Protection Department of Lai Chau province, Lai Chau, Vietnam
}

*E-mail: hanhtamle10_2012@yahoo.co.uk

Received: 09 Oct 2015. Published: 20 Dec 2015. Keywords: Phyllanthus urinaria

Chamber bitter, Phyllanthus urinaria, is a widely used herbal medicine that has been reported to possess various biological activities with anticancer effects (Huang et al., 2003). Chamber bitter plants have been cultured intensively in large areas for commercial medical production in Vietnam and China. Powdery mildew was found on this species at the National Institute of Medicinal Material in Hanoi during winter 2013, as well as on other species in nearby fields. Whole plants were covered almost completely by white fungal colonies giving the impression of having been sprayed by powdered lime (Fig. 1). Disease incidence reached approximately $85 \%$ resulting in an approximately $60 \%$ loss in yield. Two representative specimens were deposited in the Plant Protection Research Institute Herbarium (Accession Nos. PPRI-PM054 and PPRI-PM055) in Hanoi.

Microscopic examination showed conidiophores had a catenescent form of conidiogenesis and were composed of 1-3 cells, measuring (76-)78-117(-120) um long. Conidiophore foot-cells were curved with a twist at the base and measured 58-65(-68) x $4 \mu \mathrm{m}$ (Fig. 2a, b). Conidia were produced in chains and were small, doliiform, ellipsoid to cylindrical in shape, measuring $15-20(-23) \times 8-10 \mu \mathrm{m}$ with a length/width ratio of (1.5-)1.8-2.7(-3.0). Conidia had no fibrosin bodies, but inclusion-like oil drops were present and germinated with Microidium-type germ tubes (Fig. $2 \mathrm{c}, \mathrm{d})$. No chasmothecia were found. Appressoria on mycelium had lobe or nipple shapes. The morphological characteristics were consistent with descriptions of Microidium phyllanthi (To-anun et al., 2005; Braun \& Cook, 2012). To confirm the identity of the causal fungus, the complete ITS regions of rDNA from the above specimens were amplified with primer pairs ITS1/P3 (White et al., 1990; Kusaba \& Tsuge, 1995) or HF1/ HR4 (Tam et al., 2015) and directly sequenced. The resulting sequences of 645 and $700 \mathrm{bp}$, respectively, were deposited in GenBank (Accession Nos. KM260738, KM260739, respectively). A GenBank BLAST search using the present data revealed that these ITS sequences shared $100 \%$ identity with those of Microidium phyllanthi (AB719943).

Pathogenicity was confirmed through inoculation tests by gently sweeping conidia with a pen brush from diseased leaves of chamber bitter onto young leaves of 10 two-month-old potted seedlings of $P$. urinaria. Ten noninoculated seedlings were used as controls. Plants were maintained in a glasshouse at $24-26^{\circ} \mathrm{C}$. Inoculated leaves developed symptoms after nine

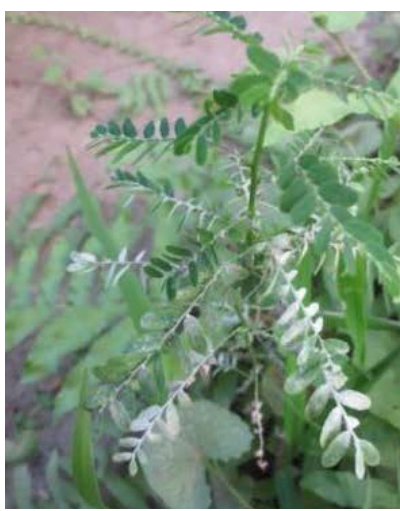

Figure 1

To cite this report: Tam LTT, Hoai HT, Thao LP, Huong NT, Khue NM, 2015. First report of Microidium phyllanthi causing powdery mildew on chamber bitter in Vietnam. New Disease Reports 32, 32. http://dx.doi.org/10.5197/j.2044-0588.2015.032.032

(c) 2015 The Authors

This report was published on-line at www ndrs org uk where high quality versions of the figures can be found.

days, whereas the control plants remained symptomless. The fungus present on the inoculated leaves was morphologically identical to that observed on the original diseased leaves, with the same sequence being produced following the PCR protocol described above, fulfilling Koch's postulates.

According to Braun \& Cook (2012), M. phyllanthi has a host range on other Phyllanthus species, including $P$. acidus, $P$. amarus, $P$. niruri, $P$. reticulatus, $P$. rheedii and $P$. urinaria with distribution in Africa (Ghana and Mauritius) and Asia (India, Indonesia, Sri Lanka, Taiwan and Thailand). To our knowledge, this is the first report of $M$. phyllanthi infection of $P$. urinaria in Vietnam. This report is significant as this disease is affecting commercial production for medical use of chamber bitter in Vietnam and control measures are being sought.

\section{References}

Braun U, Cook RTA, 2012. Taxonomic manual of the Erysiphales (powdery mildews). CBS Biodiversity Series 11, 1-707.

Huang ST, Yang RC, Yang LJ, Lee PN, Pang JH, 2003. Phyllanthus urinaria triggers the apoptosis and Bcl-2 down-regulation in Lewis lung carcinoma cells. Life Sciences, 72, 1705-1716.

http://dx.doi.org/10.1016/S0024-3205(03)00016-X

Kusaba M, Tsuge T, 1995. Phylogeny of Alternaria fungi known to produce host-specific toxins on the basis of variation in internal transcribed spacers of ribosomal DNA. Current Genetics 28, 491-498. http://dx.doi.org/10.1007/BF00310821

Tam LTT, Dung PN, Liem NV, 2015. First report of powdery mildew caused by Erysiphe cruciferarum on Brassica juncea in Vietnam. Plant Disease (in press). http://dx.doi.org/10.1094/PDIS-06-15-0678-PDN

To-anun C, Kom-un S, Sunawan A, Fangfuk W, Sato Y, Takamatsu S, 2005. A new subgenus, Microidium, of Oidium (Erysiphaceae) on Phyllanthus spp. Mycoscience 46, 1-8. http://dx.doi.org/10.1007/s10267-004-0202-z

White TJ, Bruns T, Lee S, Taylor J, 1990. Amplification and direct sequencing of fungal ribosomal RNA genes for phylogenetics. In: Innis MA, Gelfand DH, Snisky JJ, White TJ, eds. PCR protocols: A guide to methods and applications. Academic Press, New York, 315-322.

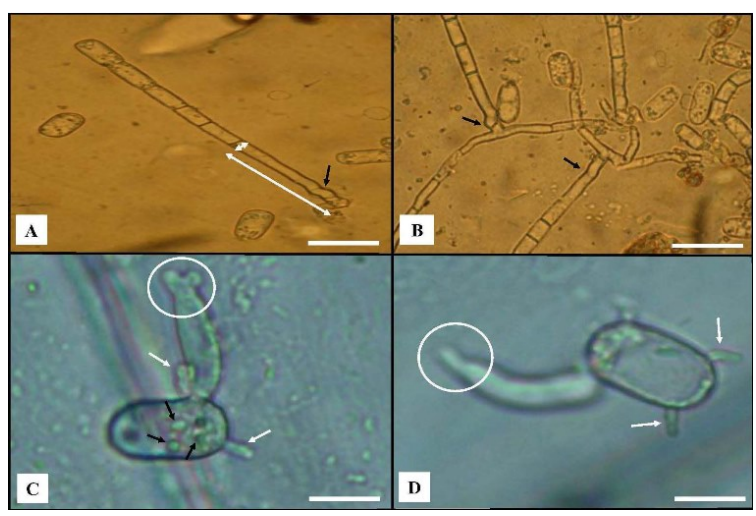

Figure 2

New Disease Reports is a peer-reviewed on-line journal published by the British Society for Plant Pathology

for more information visit http://www.ndrs.org.uk/ 